\title{
Party Membership in Romania: Political Legitimacy, Party Finance and Organisational Changes
}

\author{
ALEXANDRA IANCU* \\ University of Bucharest \\ SORINA SOARE \\ University of Florence
}

\begin{abstract}
The article retraces the contradictions between the regulations and the practices shaping Romanian party membership in order to show why and how membership decline became an electoral-driven strategy. It contrasts high membership figures, the dynamics of legal definitions of party membership, and party routines. The results indicate that the Romanian example is an atypical case of incongruence between organisational configurations and party models of 'constitutionalisation'. The frailty of party organisations in this post-communist country depends not only on the broken linkages between state and society but also on exogenous factors, such as the anti-corruption campaign and opportunistic intraparty agreements. The study uses a qualitative content analysis of party laws, party statutes, official statements, and desk research.
\end{abstract}

Keywords: Romania, party membership, party regulation, organisation, finances

Sociologický časopis/Czech Sociological Review, 2020, Vol. 56, No. 3: 315-341

https://doi.org/10.13060/csr.2020.020

Members of political parties were once active participants in shaping representative democracies [Kosiara-Pedersen, Scarrow and van Haute 2017: 234; Scarrow 2017: 1-2]. However, new case studies cast doubt on the consistency between the empirical evidence and normative views on party organisations [Kölln 2015; Gauja 2015]. The Romanian case is an outlier in post-communist Europe in terms of membership strength and continuity. Even after the recent reforms, which practically removed any meaning from party grassroots, parties such as the Romanian Social Democrats (PSD) continue to claim more than half a million party

\footnotetext{
* Direct all correspondence to: Alexandra Iancu, Faculty of Political Science, University of Bucharest, e-mail: alexandra.ionascu@fspub.unibuc.ro; Sorina Soare, School of Political Sciences Cesare Alfieri, Department of Political and Social Sciences, e-mail: ssoare@unifi.it.
} 
members [Hotnews 2015]. These records are far from mirroring the weakness of party organisations in other post-communist countries (i.e. the Czech Republic, Hungary, Poland, and Slovakia; see, e.g., van Biezen, Mair and Poguntke [2012: 28]). Nor does the empirical evidence match another outlier, namely the Bulgarian case [Spirova 2005]. In the latter instance, the steady decline in membership over the past decade suggests a new tendency towards party membership decline (e.g. the Bulgarian Socialist Party lost half its 210000 members between 2009 and 2016).

At first glance, Romanian parties succeeded in balancing the reduced costs of formal party membership and increased benefits for party affiliates [KosiaraPedersen, Scarrow and van Haute 2017]. National-level supply factors, coupled with the 'advantages of traditional membership at a lower cost' [Kosiara-Pedersen, Scarrow and van Haute 2017: 234], could easily explain the transformation to a loose mass-party model of politics. Nevertheless, this coherent structure of formal incentives that made having high membership figures important unexpectedly ended in 2015. Under current regulation, only three members are required to register a party.

In order to understand the patterns of party membership in post-communist Romania, our main research question is: what features characterise party membership in post-communist Romania? In order to provide an answer, this study focuses exclusively on the parties that have existed since the fall of communism and that have been continuously represented in parliament. The parties that meet these criteria are: the Social Democratic Party (PSD), the National Liberal Party (PNL), and the Democratic Liberal Party (PDL). In the disaggregated data we have included the Democratic Alliance of Hungarians in Romania (UDMR), the main political organisation of the Hungarian minority. Although it does not legally function as a political party, the UDMR has been continuously represented in parliament. In total, the above-mentioned parties account for more than $50 \%$ of the total party membership in Romania.

This exploratory case study contributes to the literature on political parties by questioning the conventional wisdom on the relationship between institutional reforms, party configurations, and membership decline. It argues that the Romanian case illustrates an atypical case of incongruence between the costs that parties have to assume in terms of efforts to identify and enrol supporters and the potential benefits of targeting ordinary members [Achury et al. 2018; KosiaraPedersen, Scarrow and van Haute 2017]. The 2015 state-originated 'downgrading' of party members seems to have been a self-preservation attempt, allowing mainstream parties to ensure they maintain hegemonic positions in the party competition. These reforms have de facto reinforced the status quo: the same (old) parties are the main beneficiaries in terms of the flow of public funding.

The article is based on a content analysis of party laws, party statutes, official statements, and desk research. With regard to party membership, we used 'objective' figures provided by parties to the Court of Bucharest, self-reported membership based on internal party documents, reports, and/or official state- 
ments. The data refer to individual party membership covering almost three decades of post-communism, and as such exclude potential nuances with regard to different categories of membership. One caveat must be mentioned since we are aware of the limitation of using self-reported membership data from parties, especially in the case of suspiciously round figures. For example, in June 1998, the Barometer of Public Opinion (BOP) showed that only 3.6\% of respondents were party members. However, another $22.4 \%$ refused to reply (or opted for 'I don't know'). In a similar vein, in November 1998, the BOP recorded contrasting results. Only $1.8 \%$ of the respondents openly declared being party members, while another $15.9 \%$ did not know or did respond to the question. Given this discrepancy among those acknowledging membership, party records, and the high percentage of non-responses, we agree with numerous party scholars who have stressed the fact that the reliability of mass surveys is undermined by the small population of reference, the absence of continuous measurements, and uncertainties linked to survey respondents' understanding of what party membership means [Verba et al. 1978; Mair and van Biezen 2001; van Haute and Gauja 2015].

In what follows, after a brief overview of the different theoretical explanations concerning the decline in party membership (section 1 ), the article provides a brief overview of the parties under scrutiny (section 2). The third section tackles the eclectic dimensions of partisan affiliation in Romania. By looking at the individual parties' trajectories, the fourth second section will reveal the constant presence of high enrolment figures within the main Romanian parliamentary parties and their mass party features, based on internal party documents and practices (the endogenous party constraints). The fifth section will lead into a general exploration of the varying meanings given to 'party membership' by exogenous factors (i.e. the legal provisions). Returning to the research question, the conclusion examines some possible interpretations.

\section{An overview of party activism and party membership decline}

In the context of rapid social, economic, and cultural change, the erosion of traditional social linkages, the rise of new forms of political participation, and the ever-closer relationship between parties and the state have simultaneously affected both parties and citizens. The deep reconfiguration of the 'parties as linkage' paradigm involved both supply- and demand-side explanations [van Haute and Gauja 2015]. While citizens have become more reluctant to join political parties and privileged apathy or new forms of participation have emerged, parties have progressively reassessed the costs and benefits of traditional membership recruitment and oriented themselves towards public institutions and elected offices [van Biezen, Mair and Poguntke 2012]. The consequences of these transformations have been directly connected to the quality of democracy, which no longer places the notion of popular control or electoral accountability at its centre [Mair 2006]. 
The empirical articulation of new party models redefined the expectations of the literature in terms of party membership configurations [Scarrow 2015]. Party members became less important within party organisations. Very few parties and leaders made their lack of interest in attracting members and followers openly known [Mazzoleni and Voerman 2017]. Atypical cases continue to exist. In some cases, members have remained important as message multipliers during electoral campaigns and as sources of financial revenue. New reforms aimed at party democratisation (e.g. the democratisation of the candidate selection processes) continue to endow members with more formal attributes [see, e.g., Hazan and Rahat 2010; Pilet and Cross 2014]. Nevertheless, such changes refer primarily to a mere legitimacy function with relatively little impact on the overall balance of power within the party (e.g. influence over the party expenditure structure or candidate selection). There is a consensus within the literature that party members are not what they once were. In sociological terms, party enrolment concerns only an 'outer ring of an extended political class' in which it is possible to find civil servants or other party clientele [van Biezen, Mair and Poguntke: 39]. Diminishing the costs of affiliation (e.g. online registration, lower membership, fees) and increasing the selective incentives and participatory procedures (e.g. party primaries) have become the new instruments for 'saving' party organisations [Kosiara-Pedersen, Scarrow and van Haute 2017].

The criticism raised against the party as a participatory agency connects with mass-party identifiers. Quantifiable figures on membership and financial contributions and evaluations of records on the level (intent and extent) of participation in organisation activities remained the main indicators of the backbone of party affiliation during the Golden Age of party identification. However, empirical analyses of party membership broadened and completed the organisational definition of party membership. Institutional determinants such as legislative inputs-i.e. party 'constitutionalisation' or party laws or context-dependent elements requiring new cost/benefits ratios-contributed to this change [Casal Bértoa and Spirova 2013]. A certain degree of homogenisation owing to international pressures and standards also occurred. Under the definitions adopted by international bodies, parties remain important as participatory agencies, and good party democratisation practices should support inclusive and deliberative membership structures (e.g. the Code of Venice Commission recommendations). There have only been a few attempts to explain the entire structure of incentives built up around parties (see, for example, the recent 'Project on Political Parties Database'; Poguntke et al. [2016]). If members become more involved in party organisations, this ideal should, according to current standards, exclude the mass-party model of clientelism and co-optation based on self-interested participation in party life. In a similar vein, the benefits to the party of counting high membership figures are currently contested.

While most of the literature seeks to reconcile new party layers (parties' internal adaption processes and new forms of regulations), in practice, particu- 
larly in new democracies, the various layers of party membership raise additional questions regarding potential inconsistencies or even normative clashes in explanations of membership decline [Gauja 2015; Gherghina, Iancu and Soare 2018]. The optimistic view still underpins the three main and complementary functions of party members. First, members perform a symbolic function (as part of the rhetorical quest to legitimise electoral competitions). Second, members remain valuable assets within party organisations in supporting internal party democratisation-although practices often lag behind in terms of party decentralisation or deliberative routines, members are a part of the party's rules and political activities, but in some cases they also remain providers for the party. Third, members become a juridical criterion of a party's existence (as formalised by party laws and financial constraints). According to this optimistic view, the decline of party membership is only a consequence of major changes in society, multilevel governance, and the decline of party ideologies [Katz and Blyth 2005; Mair 2006]. At the same time, the changes in the symbolic and the organisational roles of party members are merely the result of a process of party adaptation (a survival strategy) to a continuously changing and challenging environment. Nevertheless, this article posits a different interpretation. Although political and socioeconomic contexts remain essential for comprehending party change, we argue that the incongruence in the evolution of different facets of party membership (namely amongst the symbolic, endogenous, and exogenous dimensions) could also contribute to a better understanding of membership decline in contemporary democracies.

\section{Romanian parties in context: continuity and change}

The literature widely agrees that post-communist party systems have suffered from profound instability and shallow ideological positions. The Romanian example is no exception in this regard. The eight general elections held after 1990 have shown a continuous variation in the effective number of parties, which have often split, merged, or-more or less radically—changed their ideologies. This state of affairs can easily be explained in the light of the challenging process of party formation in the early 1990s. Given the lack of an articulated dissident movement during Romanian communism and the limited pre-communist democratic tradition, the new parties had to invent themselves from scratch and present a new logic of legitimacy. The polarisation of the political system echoed the political tension between post(anti)-communist and ex-communist parties [Mungiu 2018; Soare and Preda 2015; Gherghina 2014]. In the early 1990s, the former laid claim to the interwar democratic legacy and dissident positions during the communist regime, while the latter (also labelled 'successor parties') mainly sought to legitimise themselves as new forces created by the revolutionary movement. After 2000, this divide rebranded into the opposition between the pro-European reformist camp (also endorsing zero-tolerance anti-corruption policies) and, on 
the other side, a more nationalistic-distributive camp with a Euro-sceptic twist [Mungiu 2018].

Unlike in other CEE countries, in Romanian politics the inheritors of the former Communist Party dominated the first years after the fall of communism. The National Salvation Front (FSN), created in 1990, benefited from 'huge membership, strict hierarchical structure, and unparalleled penetration at the local level' [Stan 2010: 383]. Starting in 1992, the FSN split into two main factions. The conservative wing became the Party of Social Democracy in Romania (later called the Social Democratic Party / PSD). Meanwhile, the more moderate wing became the Democratic Party (PD). Both organisations survived on the political scene, constituting, until recently, two of the main pillars of the political system. The PSD consolidated itself as the main party on the left, illustrating a success story of 'redeemed communist inheritance' [Grzymała-Busse 2002: 19-69]. The party adopted redistributive economic policies coupled with conservative social reforms (for example, in 2018, the PSD even endorsed a referendum 'for the traditional family', intended to constitutionally safeguard the definition of marriage as a union between a man and a woman). In the case of the PSD, the ideological eclecticism regularly paid off; since its creation, the PSD's parliamentary electoral success has doubled through constant victories at the grassroots' level (Table 1), and it has displayed an organisational strength similar to that of other socialdemocratic parties in the region [Grzymala-Busse 2002]. The PSD won landslide victories in local elections (winning a third of all mayoral positions) and regularly boasted high membership figures. Conversely, its twin organisation, the PD, did not follow the same path (Table 1). Its ongoing quest for differentiation from its original roots was conducive to a major shift in the party's identity. The PD left behind its social-democratic claims and moved towards liberal-conservative discourses in the 2000s (culminating with its alignment with the European People's Party in 2006 and a change in name in 2007-to become the Liberal Democratic Party / PDL). From an organisational perspective, the party mainly relied on leaders with a high national profile, mustering low electoral support across the counties, albeit while preserving a limited number of territorial strongholds. With the notable exception of the 2008 elections when the PDL, in government at the time, managed to double its initial score in the mayoral contests, the party routinely obtained around $15 \%$ of votes in local contests. Altered by numerous party divisions and dramatic programmatic shifts, the internal organisational arrangements witnessed successive reforms, varying from centralised patterns of decision-making in the early 1990s towards an enhanced type of low oversight (i.e. local and county organisations were allowed to develop their own rules of functioning within the national statutory frameworks). After the 2012 elections (and a significant electoral decline), in November 2014 the party merged with the National Liberal Party.

In the aftermath of the regime change, the creation of the FSN was initially balanced by the formation of numerous small (historical) parties. They reunited 
in 1991 under the umbrella of an anti-communist alliance: the Democratic Convention in Romania (CDR). As in other post-communist countries [van Biezen 2003], this political conglomerate encapsulated primarily parties claiming a prewar/interwar legitimacy. The CDR was mainly structured on two main pillars: the Christian-Democratic National Peasants' Party (PNTcd) and the National Liberal Party (PNL). Their rather ex nihilo post-revolutionary emergence and their urban branches were conducive to fluid organisational structures, which was reflected in low scores in local elections. The PNTcd's trajectory confirmed the rapid electoral decline of the 'historical parties' across the post-communist setting. After the 2000 elections, only the liberals survived the collapse of the CDR (Table 1). With a highly ideological discourse and anaemic territorial-organisational structures, the PNL formally adjusted its internal functioning during the early 2000s. The party underwent a series of internal reforms intended to increase its organisational capacity (such as the distribution of appointed positions to the most effective local branches; see section 3). Consequently, the PNL's local performances steadily increased (reaching around 15\% of votes in local competitions in 2004) but remained overshadowed by the social democrats' electoral success. After 2012, the PNL became the main party on the right side of the political spectrum, identifying with pro-Europeanist stances and anticorruption platforms. More recently, new parties or political movements (such as the creation of the Save Romania Union-USR, an anticorruption political movement) are challenging the liberals' position.

The initial divide between post-communists and ex-communists rapidly faded. Since the late 1990s, numerous governmental coalitions and electoral agreements have been put in place in both the national and local arenas. The most illustrative collaboration dates back to 2011, when two of the main traditional opponents, the liberals and the social democrats, decided to create the core of a political alliance (the Social Liberal Union-USL), which included a joint platform and shared candidacies in both the national and local elections. The success of such eclectic ideological collaborations produced a blurred articulation of the party system. The only enduring tension is a secondary political divide between nationalistic and anti-nationalistic positions [Preda and Soare 2015]. Rapidly configured after the demise of communism, this tension consists in the opposition between the representatives of the Hungarian minority and other parties presenting extremist and anti-Magyar claims-some of which have ceased to exist. The Hungarian Democratic Alliance (UDMR), which is not a party per se but an organisational umbrella that comprises multiple programme platforms, has played a pivotal role on the governmental scene, focusing on a single-issue dimension: ethnic minority representation. With a membership structure declining in step with the decline of the Hungarian minority demographic, the UDMR consistently obtains around $4 \%$ of the vote in mayoral elections. 
Sociologický časopis/Czech Sociological Review, 2020, Vol. 56, No. 3

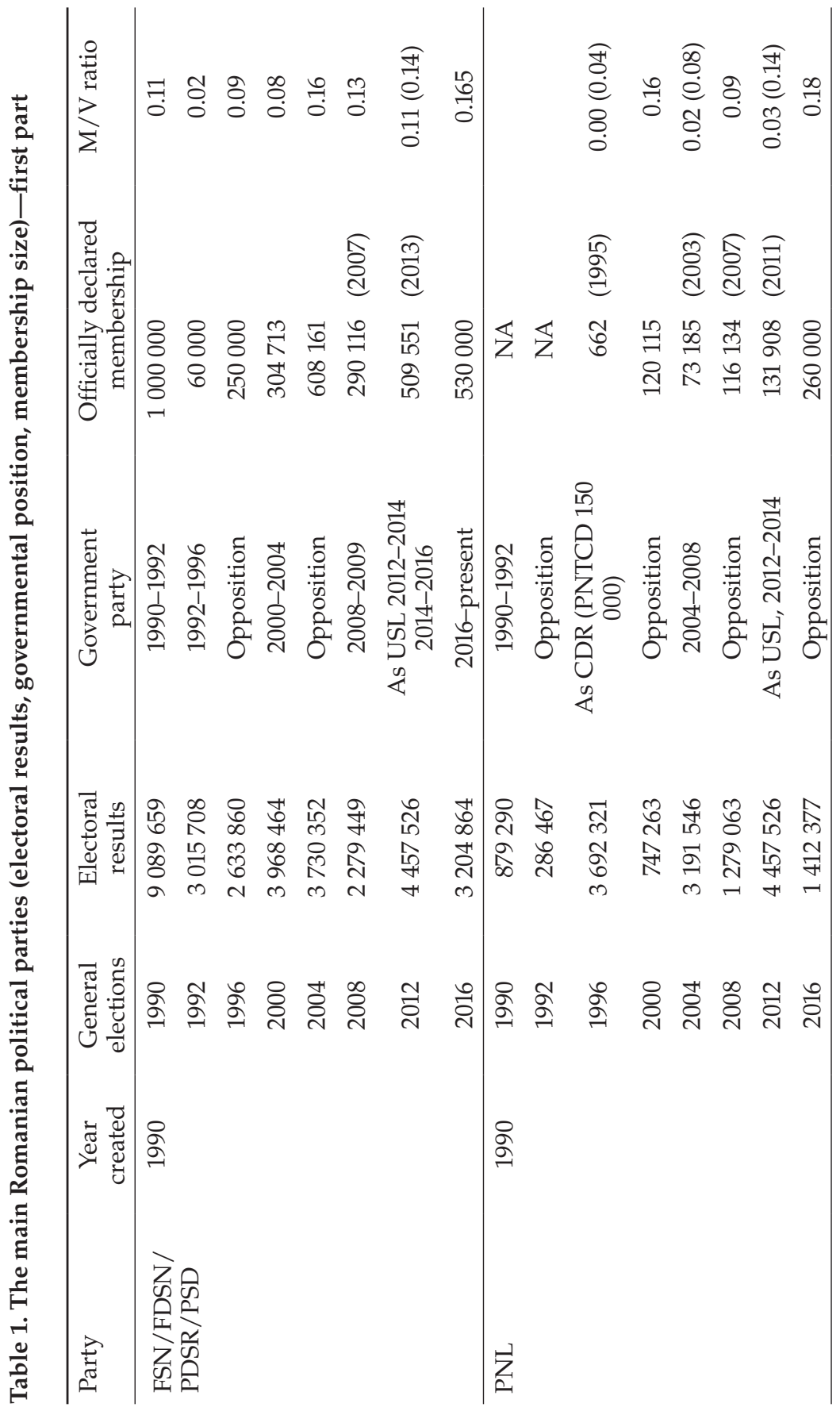




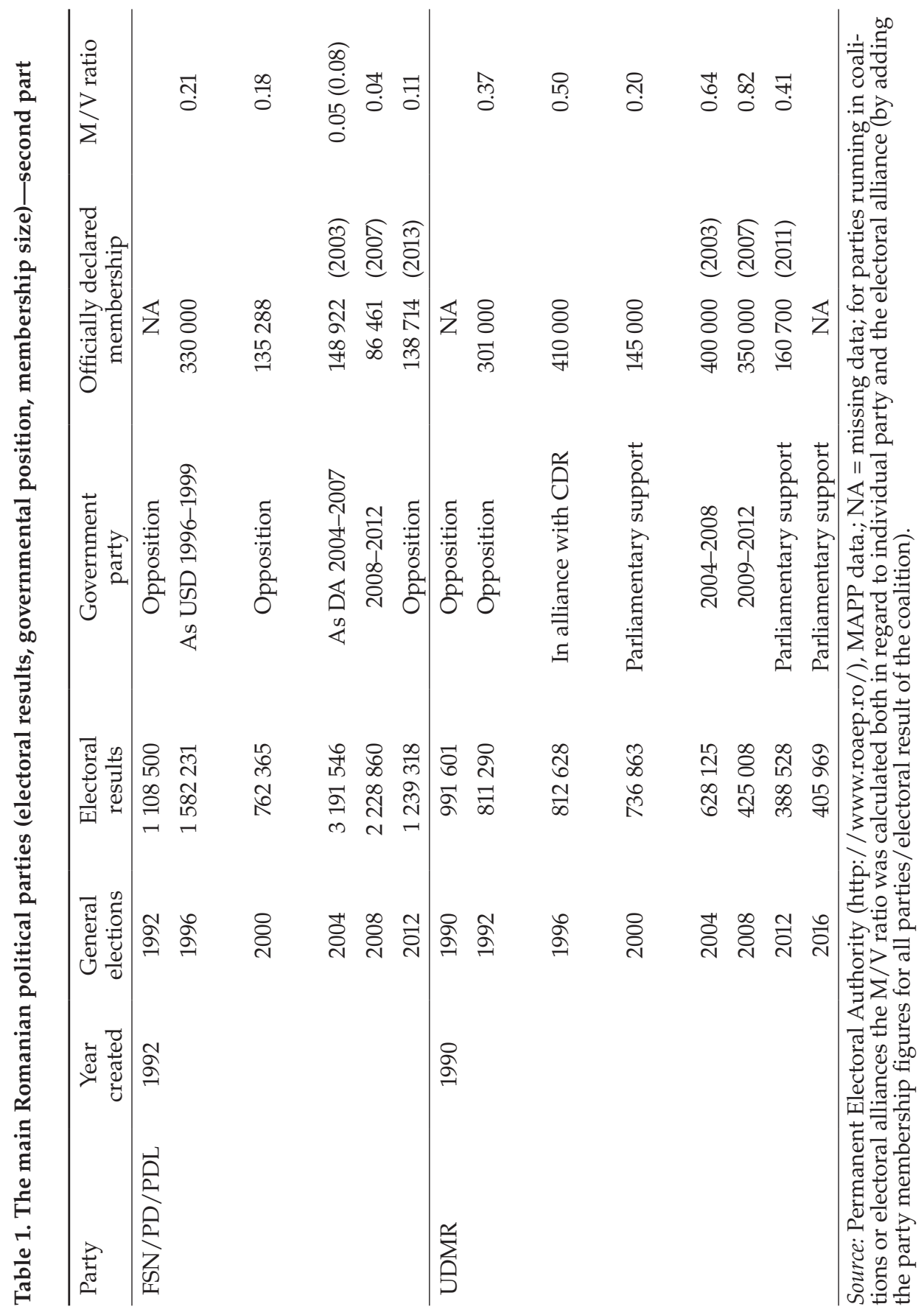




\section{Party membership in Romania: high enrolment or wishful thinking?}

Romanian membership data indicate a mixed landscape. From the mid-1990s onwards Romanian parties became a regional exception, with $12 \%$ of the citizens declaring a party affiliation in the World Values Survey, well above the Central and Eastern European average of 5.9\% [Howard 2003: 66]. Despite constant evidence in favour of citizens' disenchantment with parties (e.g. limited trust, declining participation), in the mid-2000s Romanian party membership progressively stabilised. The decrease in the number of registered parties and electoral competitors since 2008 seems to support this claim. While 71 parties or coalitions were registered in the early 1990s, their number gradually declined to 12 in the 2012 elections. According to the M/E ratios (i.e. the number of members as a percentage of the electorate) reported by van Biezen et al. [2012: 28], membership figures put Romanian parties above the European average of 4.7 in the mid-2000s. In a similar vein, a more recent survey of party organisations showed that the average European M/E ratio recently declined to 3.13 [Poguntke et al. 2016: 668]. This suggests that, with the exception of Austria in 2011, Romanian parties declare the highest number of members at the European level. The relative anomaly of the Romanian case can be fine-tuned with a stricter methodological evaluation. If we equate party relevance to presence in parliament, the data relating to the 1990-2000 elections remain unchanged (Tables $2 \mathrm{a}$ and $2 \mathrm{~b}$ ). This lack of variation is due to the fact that the individual membership figures refer to a rather limited number of parties (all of them parliamentary parties): two (out of seventeen parliamentary parties) in 1990, three (out of twelve) in 1992, five (out of twelve) in 1996, and five (out of seven) in 2000. In general, the collection of data on party membership over time is complicated.

In the Romanian case, the data for the 1990s are incomplete, not only for minor parties, but also for the main competitors. Until 2003, political parties did not maintain a rigorous record of their membership figures. As a direct consequence, the limited number of parties included in the 1990-2000 computations may slightly underestimate the total number of members for this period and the different ratios. After the adoption of a new party law, all parties had to adapt their data management practices and maintain more accurate membership logs. As a result of this, the level of detail increases after 2003, when twenty parties were included in the dataset. One specific caveat must be mentioned in relation to the post-2003 figures, which are for the most part based on the official party lists of supporting signatures required by the registration procedures. These declarations refer only to a minimum threshold, with parties providing a discretionary interpretation of the upper limits of their declarations. Another important aspect concerns the discrepancy between the global figures relating to all registered parties (Table 2a) and parliamentary party membership (Table 2b): -466 738 (2012), -715 794 (2008), and -574 073 (2004). In other words, a significant number of Romanian citizens participate in electorally unsuccessful political organisations: $2.53 \%$ of the entire electorate in 2012, 3.88\% in 2008, and 3.11\% in 2004. From 2008 
Table 2a. Romanian party membership across seven post-communist elections (1990-2014)

\begin{tabular}{lccccccc}
\hline & 1990 & 1992 & 1996 & 2000 & 2004 & 2008 & 2012 \\
\hline Total party & 1800000 & 376000 & 1212000 & 923118 & 2101482 & 1649168 & 1418057 \\
membership & & & & & & & \\
M/E & 10.46 & 2.30 & 7.04 & 5.22 & 11.39 & 8.93 & 7.70 \\
$\mathrm{M} / \mathrm{V}$ & 13.13 & 3.01 & 9.26 & 7.99 & 19.55 & 22.78 & 18.43 \\
$\mathrm{M} / \mathrm{P}$ & 7.76 & 1.65 & 5.36 & 4.14 & 9.40 & 7.48 & 6.49 \\
\hline
\end{tabular}

Source: Total party membership expressed as an absolute number (M), party membership expressed as a fraction of the total electorate $(\mathrm{M} / \mathrm{E})$, of effective voters $(\mathrm{M} / \mathrm{V})$, and of the total population (M/P). Because the data are incomplete for the 2004, 2008, and 2012 electoral years, the computations took into account the data from the year before the elections. In the case of the PSD, we relied on the party's internal statistics.

Table 2 b. Parliamentary party membership across seven post-communist elections (1990-2014)

\begin{tabular}{lrrrrrrr}
\hline & 1990 & 1992 & 1996 & 2000 & 2004 & 2008 & 2012 \\
\hline $\begin{array}{l}\text { Total } \\
\text { parliamentary } \\
\text { party } \\
\text { membership }\end{array}$ & 1800000 & 376000 & 1212000 & 923118 & 1527409 & 933374 & 952319 \\
M/E & 10.46 & 2.30 & 7.04 & 5.22 & 8.39 & 5.06 & 5.17 \\
M/V & 13.13 & 3.01 & 9.26 & 7.99 & 14.40 & 12.89 & 12.38 \\
M/P & 7.76 & 1.65 & 5.36 & 4.14 & 6.92 & 4.23 & 4.36 \\
\hline
\end{tabular}

onwards, the evidence based on parliamentary parties exclusively shows that Romanian values draw closer to European averages.

Romania's high levels of party membership also remain visible in the analysis of the main parties' individual trajectories (Figure 1). Looking at the post-2003 period - the period for which more comparative data are available-the absolute values of the main party enrolment figures reflect the fluctuation described above, with an abrupt decrease between 2003 and 2007. The decline tends to flatten out more recently. Within our sample, there is large variation. The Social Democrats have fared better than the other competitors: they have succeeded in maintaining significant membership, with a major increase in recent years, based on a traditional definition of party membership (in 2016 the PSD reported 530000 members). At the opposite end of the pole, the Liberal Democrats (PDL) and the Liberals (PNL) maintained a stable number of party loyalists. Their merg- 
Figure 1. A comparison of M/E ratios: aggregate and individual party ratios (1996-2012)

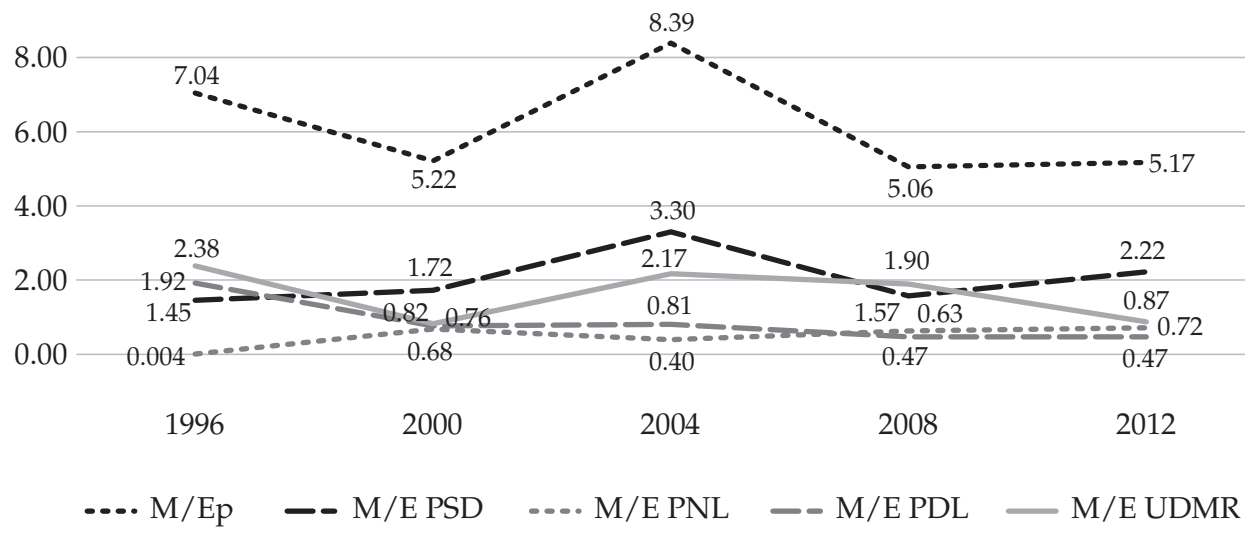

er in 2014 increased their membership base to 260000 members. In fact, the only party that has seen a decline in its membership base is the Alliance of the Hungarian Minority (UDMR), which, although it has preserved its important ability to mobilise the ethnic Hungarian population, is facing a significant demographic decline (down 14.26\% in 2011 compared to the 2002 census), factionalism, and new electoral contenders. The reform of the party law did not tame political parties' interest in broad membership, at least in terms of party leaders' declarations: in 2017, according to statements by part leaders at least 2 million people were enrolled in a political party [Gîrlasiu and Duța 2017]. These optimistic ('objective') accounts should be balanced with subjective measurements of party membership (i.e. comparative surveys on political participation, such as the European Values Study, or national surveys). Further, the quality of the available 'objective' data might-ideally-increase if there are amendments to the current party law, including introducing an explicit requirement for parties to disclose their membership publicly. This, however, is not a current topic of discussion.

\section{The symbolic dimension of party membership in Romania: parties' discourses of legitimacy}

Overstating enrolment is not exceptional. Parties tend to interpret high membership figures as a sign of their popularity [Scarrow 2017: 3] and Romanian parties have a long history of legitimation through high membership figures. The main exponents of this continuous quest for self-justification through party reach are the Social Democrats. The Romanian successor party was said to have one mil- 
lion members in 1990. This figure is probably an overstatement, because the FSN did not directly inherit either the PCR's membership structures or its territorial network [Pop-Elecheș 2008]. With the exception of 1992-1993, after an important split and a change in the party's name to the Party of Social Democracy in Romania (PDSR), when a radically different estimation of the enrolment figures was recorded, a mere 60000 members, the PDSR (now known as the Social Democratic Party-PSD) has never fallen below the threshold of 250000 members.

The leaders of the Social Democratic Party openly stated their mass membership-oriented party-building strategy, as a way of justifying their post-communist trajectory. This strategy generated a visible and rapid increase in members, up to almost 700 000. According to party statistics, the early 2000s represented a phase of party consolidation, with an increase from 304713 members in 2000 to 694654 in 2001 and 659013 in 2002. Although party membership declined in 2007-2011, the PSD has outstanding numbers (the Social Democrats had 409833 members in 2011 and 535699 in 2015). More recently, the party continued with its aggressive recruitment drive. In 2017, the party's leaders declared 547850 paying members and 811000 persons who held a membership card. While leaders tend to overestimate enrolment figures, it should be noted that these figures correspond to the figures published by the party for direct membership votes. In the 2015 leadership contest, 435172 people voted in the election of the party president (out of 535699 officially registered members) [Hotnews.ro 2015]. Without specific party membership surveys, it is difficult to state who these members are or what motivates them to join the party. According to the 2011 PSD census, current PSD members are mostly male (59\%), tend to be elderly, and have low to medium levels of education.

Party members are an important part of the party's narrative. From the early 1990s, the PSD tried to brand itself as the party of renewal and of the people. With deep roots in rural areas, the party often relied on electoral patronage and clientelism. In recent times, this rhetoric remains, but for different reasons. Contemporary Social Democrats continue to stress that the party is primarily dependent on membership fees and party activists in order to counter the current allegations against its leaders regarding illegal party financing and electoral and governmental corruption. In June 2018, for example, the Social Democrats displayed their organisational strength by mobilising around 180000 people in front of the Romanian government building as a show of support for the current government. This mass mobilisation followed Victor Orbán's strategy in Hungary of countering anti-governmental protests with demonstrations of his own.

The other heir to the FSN, the Democratic Party (PD) also looked for organisational strength (330 000 members). In the mid-1990s, the PD (which became the Liberal Democratic Party or PDL in 2007) exhibited similar numbers to the PSD, its main contender, with around 330000 members in 1996. Its grassroots base shrank to around 90000 supporters in the early 2000s. In the years that followed, the party looked for new strategies to reinforce the membership base. The PDL developed at the same time as another party opposing the Social Democrats: the 
National Liberal Party (PNL), with which it later formed an alliance. For the PNL, the process of member centralisation started in 2000, with no systematic data collected in the early 1990s. In the 2000s, the PNL membership base remained constant, with a slight increase in recent years. By the end of 2014, the alliance between the PDL and the PNL publicly declared they shared 260000 members (PDL: 138714 members and the PNL: 115181 members). While there are no public records on the general profile of the PNL's or the PDL's membership, a survey of party delegates in 2007 revealed a general tendency in both parties to preserve the 'elite character' of the party: primarily men (PNL 88.5\%, PDL $80.2 \%$ ), active in society (PNL 93\%, PDL 93.4\%), aged between 40 and 59 years old (PNL 63.6\%, 61.3\%), and highly educated (PNL 87.8\%, PDL 96\%) [De Waele and Ionașcu 2008]. Both parties, which eventually merged in 2015, conducted several recruitment campaigns in the 2000s, highly mediatised, co-opting members from academia, business leaders, and prominent NGO figures. Despite these efforts, membership activism remains rather low. The party's recent attempts to mobilise members against the social democrats failed to reach significant numbers. Currently, the mobilising strength against the left-oriented government usually relies on nonaffiliates from major urban areas. In 2017, at the party's congress, the party president estimated the total number of party members at 'about' 200000.

The Hungarian minority party replicated the PD/PNL trajectory. Representing the main ethnic minority of the country, the alliance preserved the important capacity to mobilise the ethnic base as its survival strategy. The UDMR has constantly confirmed high numbers of members, ranging from around 160000 to 400000 (around $2 \%$ of the Romanian electorate). In order to do this, the party has tried to accommodate ideological, sociological, and regional representation within party ranks. Comprehensive qualitative data on the UDMR members is not available. If we refer to the delegates directly elected through grassroots channels to attend the 2007 party congress, the broad majority of these mid-level elites consisted of men $(84 \%)$ with a university degree and professional experience as upper-level civil servants [Ionașcu 2012].

\section{Organisational definitions of party membership: formal statutory arrangements}

How did Romanian parties construct their broad appeals to members? How did they manage to combine large numbers of affiliates? What are the costs and benefits of membership? While the literature often emphasises the idea that high enrolment figures usually co-exist with low membership costs and plebiscitary membership reforms [Kosiara-Pedersen, Scarrow and van Haute 2017], Romanian party organisational arrangements seem to contradict this assessment. In fact, parties' statutory provisions reveal different models of conceiving party affiliation, which have rapidly changed from one party congress to the next. Restrictive access conditions mirrored important membership recruitment campaigns dur- 
ing the 2000s. With the exception of the UDMR (whose statute already mentions Romanian citizenship, as well as a written letter of interest and acceptance of the programme and statutes as prerequisite conditions for becoming a member), all the other parliamentary parties introduced various specific requirements for potential members. The intensity of these requirements fluctuates over time. As a common element, parties fine-tuned their membership criteria with an increased emphasis on morality and integrity. In the absence of any existing analysis of why people join parties in Romania, it is only possible to take into account the party rhetoric used in enrolment campaigns. The official messages are focused on the desire to contribute to the party programme and to make a political difference. This is the case of the PSD's online enrolment page: it starts with a catchy motto-Dare to Believe in Romania-then continues with details on the party programme and, at the bottom of the page, provides a link to join the party. Similar strategies are identified among all the main parliamentary parties: they all tend to attract members in terms of broad political considerations. No major differences are identifiable within parties with regard to local branches. While there are no systematic data gathered on members' motivations for joining a political organisation, two Cevipol surveys conducted in 2007 and covering delegates to party congresses underpin idiosyncratic explanatory frames. In the case of the Liberals, the party delegates pointed first and foremost to ideological reasons (44\%) and 'sympathetic accounts' towards the party (8.8\%) in explaining why they had chosen the PNL. Others identified the party as 'serious' and 'important' (9.1\%), while in $7.7 \%$ of cases family tradition played an important role [De Waele and Ionaşcu 2008]. The PDL members also emphasised the ideological dimension (the party's ideals and programmes), but to a lesser extent (18.62\%). Instead, more delegates pointed to the importance of party characteristics, such as the quality of the party's leadership or the structure of its incentives ('good statutory provisions') - totalling 37\%. Another 18\% pointed to the party's role in democratising the country and combating corruption, while $17 \%$ quoted different personal reasons. Note that the media tell a rather different story, which emphasises a more pragmatic strategy of joining the party for personal career/financial considerations [De Răzvan 2016].

The volatile and fluid definitions of party membership have often differed depending on whether the party in question is in government or opposition. In 2003, the PNL explicitly aimed to strengthen local structures by implementing a rule according to which sympathisers were able to enter the party exclusively in their local branch. When in government, changes within the PNL's regulations eliminated these restrictions, which had become obstacles to broader recruitment procedures and to co-opting new supporters who had previously been members of other parties. The PDL moved in the opposite direction and introduced additional clarifications aimed at gatekeeping the recruitment process. Initially, the party's statutes indicated that a simple letter of intent sufficed in order to join the party. In 2010, while the party was in government, vague qualitative requirements were included, referring to 'people appreciated and known to be honest 
and competent citizens who can contribute to the achievement of the party goals' (art. 14 (1c)). Meanwhile, a new statutory prohibition referred to persons identified as collaborators with the communist political police, those who had held paid positions within the hierarchy of the Communist Party or promoted ideas or actions of racism, xenophobia, anti-Semitism or intolerance (art. $14(2 b, d))$. These requirements were in line with the party's commitment to promote a lustration bill and a 2006 report condemning the acts of the communist regime. Following the merger of the PNL and the PDL, the new party stuck with the same ideological forms of legitimation. Recent statutory stipulations have focused on the political integrity of future members, such as not being convicted of any crime (corruption in particular), not having had any relationship with the former Securitate or having benefited from Nomenklatura positions during the communist regime, and not having been connected to racist or anti-Semitic statements (art. 15).

A similar open-door policy characterises the PSD's statutes. In the early 2000s, in direct relationship to its self-proclaimed revolutionary origins, the party listed a compulsory declaration endorsing the values of 'the revolution among the conditions for becoming a member'; article 7 stated that '(2) persons morally and politically compromised, including in relation to abusive actions in the service of dictatorship and totalitarianism, (3) persons convicted of acts contrary to the Romanian December 1989 Revolution ... (5) persons who promoted violence, fascist ideology, anarchism, racism, chauvinism, and any other ideas or actions of extremism or against human rights and fundamental freedoms' could not become members of the Social Democratic Party. Conversely, the 2011 party rules symbolically deleted references to the Romanian Revolution or general actions in the service of the old regime. Whereas the early 2000 statutes placed the emphasis on 'a letter of recommendation provided by a member of the PSD' (art. 5) (provision maintained in 2005), the 2011 party codes eliminated this personalised procedure of adhesion and launched a new party direction targeting intensive recruitment through online registration and bonuses. In order to cope with citizens' demands for more political integrity (and to reject allegations that the party was corrupt), the party statutes note that persons who had betrayed the country's interests or who were guilty of violent crimes could not become party members. The current statutes were clarified, and some former provisions disappeared from the text. In order to become a party member, one need only have exhibited good professional, moral, and political conduct. Thus, people who are 'morally and politically compromised' and 'people who promoted violence' are barred from becoming party members. The PSD remains a rather traditional party favouring face-to-face communication and informally continues to rely on the co-option of friends and relatives. While online enrolment is possible according to its statutory provisions, this remains an exceptional procedure targeting non-resident citizens or citizens unable to physically get in contact with a local branch of the party (art. 15(2)). On this point, it should be noted that the PSD is among the very few Romanian parties that explicitly regulates the possibility for EU citizens residing in Romania to become party members (art. 13). 
The recent changes in the party regulations underscore the mainstream parties' continuous quest to shape the ideal member and prevent public scandals. At the beginning of 2000, the PSD interpreted party membership as belonging to a personalised political group or community. The PNL implemented a more pragmatic and decentralised vision of strengthening party organisation, while the PDL's extensive codifications seem to see membership as a pre-selection phase for public office. Nevertheless, these procedural choices did not entail a particular recruitment method within party organisations. For example, starting in 2002, the PNL adopted a parliamentary selection procedure that introduces a sort of 'meritocratic criterion': the central level selected the candidates in cases where local branches had had poor electoral performances; meanwhile, at the national level, local branches with better records of electoral success were allowed to select their own candidates, subject to the approval of the Permanent Delegation. In 2010, the PDL abandoned its seniority constraints and instead adopted very narrow 'meritocratic' criteria of selection (i.e. professionalism, political experience, 'anti'-corruption provisions, etc.). Similar barriers were also introduced in the selection of the national party leadership. The PDL applied candidate selection procedures based on a list-election and a competition between candidates' programmes (called 'motions') while the PNL organised national meetings with members of the National Permanent Delegation and the delegates elected by the territorial organisations, in line with algorithms decided at a central level. Currently, the PNL follows a top-down, yet inclusive, nomination procedure (because of the considerable size of the central committee operating and sanctioning the procedure). Conversely, two other parties, the UDMR and the PSD, have chosen to introduce a more open structure of selection: party primaries for the parliamentary elections. This initiative was partially applied by the PSD in 2004 and remains operational in the case of the UDMR. In its current statutes, the PSD has implemented a bottom-up procedure for selecting party leadership. The party president is selected through party primaries. Local branches of the party (ultimately sanctioned by a narrower committee) propose party representatives for public office-MPs and MEPs.

Despite the chronological and procedural differences, what seems to unite the various party organisations is a continuous quest for party reform. Such fluidity in selection processes has continuously acted as a screening device for disloyal or factionalist practices. In fact, the process of candidate selection has been tightened up by the adoption of both extensive criteria for candidacy and highly formalised recruitment procedures. The recent party statutes have instituted multiple phases in the candidate selection procedures, involving both the central party and local party organisations, while also creating mediating committees meant to temper internal conflicts. These time-consuming procedures have become increasingly formalised. The PDL, for instance, even introduced a provision according to which a person intending to run in an electoral race should announce this intention to the county organisation at least a year in advance. The intricacies of the candidate selection procedures have also yielded some small 
benefits as they provide an idea of which party members are (directly or indirectly) more important. Similarly, in October 2018, the Liberals organised an internal competition for the EP elections. The internal procedures required the candidates to submit a professional and political $\mathrm{CV}$ and a project for future activities in the EP. While the selection was kept under the close supervision of a narrow circlethe party president and the executive committee of the party-a person was not permitted to run in the internal race without representing a euro-region and securing the endorsement of at least $50 \%+1$ of the local party branches within that region [Hotnews 2018].

Besides some isolated experiences, parties have retained a highly centralised candidate selection process. At the same time, however, party reforms in the direction of decentralisation have had some results in terms of restructuring party elites, particularly with regard to the importance of local credentials. In a gradual way, elite recruitment procedures have begun to favour territorial linkages and the endorsement of local party organisations [Iancu 2017]. The articulation of local organisations can thus provide an alternative explanation for the persistence of relatively high enrolment figures across the territory. The institutionalisation of high-profile local politicians controlling the distribution of incentives in a territorial arena does not automatically entail the empowerment of membership. While certain key figures within the local administration, such as mayors or county councillors, continue to control their constituencies, their allegiance to the parties has been repeatedly challenged. Although national party leadership has gradually become more responsive to the demands of the grassroots, local notables engage in disloyal practices and party-switching strategies [Ganev 2012].

\section{The exogenous definition of party membership in Romania: the perspective of the state}

The organisational dimension of party membership partially confirms the connection between party organisational efforts and high enrolment figures. While some reforms favoured plebiscitary means, such as direct election of the party president in the PSD, most parties chose instead to reinforce decentralisation policies within their organisations. These changes, however, were not in line with the parties' overall efforts to draft regulations intended to encourage mass membership organisations. In the early 1990s, the legislator showed little interest in party membership. In December 1989, according to the legislation, a minimum threshold of 251 members was required in order to register a party. Subsequent regulations aimed to limit the ability of new parties to enter the party system. The 27/1996 Party Law was the first example of this. Issues connected to parties' identity, activity, and funding emerged as national norms. The text stipulated detailed schemes for party statutes and their programmes and required a list of supporting signatures of at least 10000 members, from at least 15 of the country's 
41 counties (with no fewer than 300 signatures from each county) (art. 17, (1b)). Various other provisions concerned party organisation. The general assembly of the members, the supreme decision-making body of the party at the national level (convened at least once every four years), was to be comprised of delegates elected by secret ballot at the territorial level proportionally to the overall party membership. Specific provisions protected party members-they could not be excluded from the party organisation unless they deliberately violated the party's statutes. Alongside these restrictive organisational aspects, the legislation also introduced a correlation between the number of party members and funding opportunities. Precise financial criteria were set out for parties' sources of revenue, expenditure and donation ceilings, and formulas for the distribution of state subventions according to parties' electoral results. Immediately after the 2000 national elections, the PNL backed a new party law calculated to reinforce the relevance of having a broad membership. Initially, the bill required a threshold of 50000 members, but, after a presidential boycott and the mobilisation of various NGOs, the final text cut the initial requirements by half. The 2003 Party Law required 25000 members, located in at least 18 administrative departments (with a minimum of 700 members per county). The highly restrictive membership provisions were also doubled by a demand for electoral performance. In a similar vein, party finance laws also referred to provisions aimed at reducing the access of marginal or extra-parliamentary parties to public subsidies and increasing state support for mainstream political actors.

For over two decades, party regulation in Romania has been considered one of the most restrictive models of party laws in the EU. Unsurprisingly, between 1992 and 2015, very few new parties successfully overcame the institutional obstacles raised by the party registration procedures. Nevertheless, without notable party decline or readjustment, by 2015, new legal provisions endorsed by all major parliamentary parties downplayed the role of party membership: it was now possible to register a political party based on the signatures of three members, without any geographical representation criteria.

This radical amendment of the legal framework was a response, first, to contextual input in the form of protests against the grey zones in the organisation of the 2014 presidential elections. In the run-up to the 2016 electoral year, the amendment of the electoral code provided fertile ground for tackling reform of the party law. A major stimulus for change was provided by a complaint to the Constitutional Court filed by the Romanian branch of the Pirate Party in 2014, arguing that the legal requirement to file a list of 25000 members, including their personal details (art. 19 (1,3) Act 14/2003), in order to register as a party constituted a violation of various Romanian constitutional provisions and European law. It should be noted that while similar complaints had been raised in the past without success (e.g. Constitutional Court Decisions 35/1996, 147/1998, 433/2006, 954/2010), in February 2015 the Constitutional Court accepted the complaint and argued that it was necessary to take into account changes in Romanian society, 
the jurisprudence of the European Court of Human Rights, and the recommendations of the Venice Commission. In this context, increased advocacy efforts and online activism on the part of Romanian civil society openly targeted the law on political parties. One of the most commonly made arguments was that, according to the 2003 criteria, Romania had the highest required ratio of party members to citizens/voters (1 to 892 and/or 1 to 739). Beyond the obstacles to the right of association, other arguments put forward referred to the limited visibility of local interests in national politics and the need to incentivise citizens' participation in politics. In this context, the process leading to the adoption of the amendments was rapid and widely supported.

In parallel to this, parties' financial dependence on membership fees also came to an end in 2016. Previously, electoral campaigns were not subsidised by the state; parties thus depended on members as a source of revenue. The 2016 revision of the party finance law allows even small parties to receive reimbursement for electoral campaign spending. However, despite these changes, the figures available regarding party financing - although they have not been systematically collected-suggest that members continued to be a major source of support for party budgets. Since 2000, private donations and membership fees had tended to become the main sources of party finance, to the detriment of public subsidies (see Figure 2). This trend reinforced the party narratives on extensive membership recruitment. In the early 2000s, the PSD's membership revenues multiplied sixteen times, the UDMR's twelve times, and the PNL's six times. Members' subscriptions became a major source of income for the parties, representing on average almost half of their total incomes for 2003 and 2004, while, for the same period, state subsidies accounted for only a third of the total party expenditures. In 2010, membership fees represented, on average, 50\% of the Social Democrats', Liberals', and Liberal Democrats' party budgets. When compared with other democracies, the difference is striking. While, on average, the percentage of party income from direct public subsidies reached an average of $57.5 \%$ in the early 2010s, in Romania in 2012 public subventions accounted for only 11\% of the Social Democrats' and of the Liberals' revenues and just 5\% of the Liberal Democrats' budget. The only electoral competitor that directly and systematically relies on state subventions is the UDMR (76\%). The UDMR's dependence on public funding is due to the fact that the organisation is financed as an NGO under a different law regulating the representation of ethnic minorities.

The relevance of membership fees can be distinguished on two levels: relevance in non-election years and in election years. As expected, the total sum of membership fees collected in election years and in the years immediately prior to elections is greater than in non-election years. There are also strong variations across the parties. The PSD used to have the highest share of subscriptions with no major difference in terms of electoral races. The UDMR's ambiguous statutory definition of members explains the Alliance's strong dependence on other sources, such as private donations during the 2000 s and more recently state sub- 
Figure 2. Membership dues/state subsidies in the election years 2000-2016

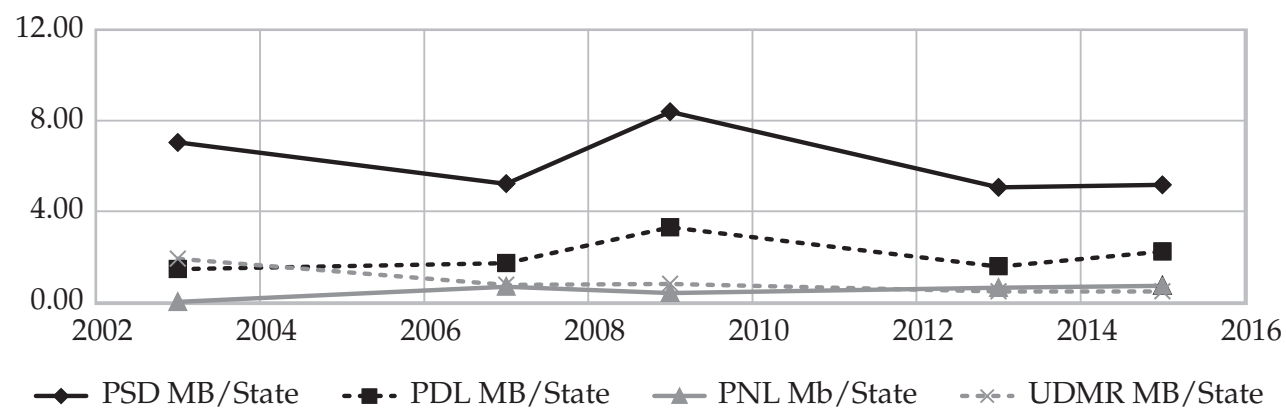

sidies. Centre-right parties, such as the PNL and the PDL, have also seen an increased role being played by party members within their organisations. While in both cases members play only a minor role in party internal affairs, grassroots networks provide increased support for these parties' finances and help to mobilise and organise electoral campaigns. In both cases, subscriptions tend to be slightly higher in electoral years. During the 2000s, both parties tended to rely more on private donations than on membership dues [Ionaşcu and Soare 2012]. Given the variability in the amount of money that different categories of members must pay as a membership fee, the official records on party incomes are not illustrative of enrolment figures. Members' subscriptions depend on the level of representation-party members pay less than party leaders or party representatives in public offices. For instance, the membership fees required from a party member in 2009 were rather low: five Ron per month (one euro) in the case of the PDL, 2.5 Ron (0.50 eurocents) for the PNL, or one Ron (20 eurocents) for the Social Democrats (which remains unchanged to the present day). However, for the top leadership positions the average fees were substantially higher: around 65 euro per month for a local PDL leader or 25 euro in the case of the Liberals. There seems to be a correlation between the leaders' salaries and subscription dues: PSD MEPs are supposed to pay around 500 euro per month in membership fees.

In 2016, the entire system of party financing-more specifically, parties' reliance on broad membership structures, which in turn enabled indirect access to private donations-was supposed to come to an end. The prohibitive categories of expenses for electoral campaigns diminish a party's propensity to look for new members and to seek financial autonomy. In 2016, membership fees still accounted for 55\% of the PSD's budget and 23\% of that of the PNL. In addition to this, $15 \%$ of the PSD's income and more than $50 \%$ of the PNL's was dependent on donations [Slăvoiu 2018]. Reports from 2017 already illustrate an important shift in internal party policies. The PSD declared that public subsidies made up $62 \%$ of the party budget, while membership fees had declined to $32 \%$. However, the per- 
centages are misleading. Compared with 2014, public subventions for the party increased 7.5-fold in 2017 and then doubled again in 2018. In fact, the entire party finance system was transformed in 2016. Owing to a last-minute amendment to the law introduced by a Social Democrat MP, which set state subventions at a fixed percentage of GDP, state finance reached impressive records (an increase of over 300\%) [Tapalagă 2018]. When this change is taken into account, it becomes clear that the mainstream parliamentary parties did not abandon members (as potential sponsors) but supplemented their contributions with a redistributive initiative based on state subventions. Mainstream parties did not break the cartel, but they found a quick way to secure their financial well-being.

\section{Conclusion: colliding explanations of party decline?}

The Romanian party system is characterised by weak party-voter linkages, high volatility, and low levels of trust in political parties. At the same time, these organisations continue their broad political engagement. The empirical dimension of our analysis provides a detailed overview of party membership in the context of an (until now) underexplored case study. In so doing, the article complements recent surveys of party organisations [Poguntke et al. 2016; van Biezen et al. 2012]. Our research also identifies additional context-driven determinants of party membership, such as the anti-corruption campaign and ad hoc intra-party agreements, confirming the thesis that multiple and idiosyncratic factors shape party grassroots in contemporary democracies [Scarrow 2017]. Romania's high enrolment figures alone are only partly exceptional if one takes into account the unexpected increase in party membership observed in some consolidated democracies (e.g. the British Labour Party).

From a theoretical perspective, the analysis confirms that party affiliation remains a context-driven concept, based on specific legislative provisions regarding party behaviour and party finance, statutory arrangements, and strategic incentives meant to facilitate and encourage the formation of active grassroots [Scarrow 2015; Achury et al. 2018]. At first glance, the different determinants of party membership may seem contradictory or to have had unintended effects. In post-communist Romania, members have been valuable assets for party organisations, a state of affairs supported not only by very restrictive legislative frameworks but also by parties' desires for legitimacy and private resources. All of the mainstream political actors seemed to nurture a preference for a modern mass-party model in which members substantially contribute to the party's definition, activities, and finances. In turn, members have developed a very utilitarian acceptance of their marginal role, since they allow parties ample room in which to operate. This model fundamentally differs from the recorded models of membership analyses in consolidated democracies, where parties mainly feature continuity and slow reconfiguration processes [Scarrow 2017]. While the importance of both symbolic and material incentive structures may have been stressed 
for Western parties as well, in the Romanian case these elements were mainly related to short-term foreseeable patronage (pre-electoral or post-electoral).

When it comes to party statutes, lowering the costs of party membership and increasing the reward structure (particularly through the adoption of plebiscitary means) has favoured some forms of party organisational reach. However, the adoption of new party democratisation reforms empowering members [see, e.g., Hazan and Rahat 2010; Pilet and Cross 2014] has proved short-lived, as solutions were only introduced in the aftermath of political crises and were temporary. Conversely, because of their unchallenged position when it comes to the production of laws and regulations in Parliament (with limited inputs from civil society), Romanian parties have maintained a favourable political opportunity structure for their own development (e.g. through regular amendments to the electoral laws, changes to party and party finance laws, etc.). Such means of incrementally constitutionalising party politics are not necessarily consistent with previous and 'organic' patterns of party consolidation.

The 2015-2016 amendments to the party laws are illustrative in this regard. The new party regulations have dismantled the previous cartel-based structure of opportunities and seems to constitute a juncture point in party development. However, the available evidence and discourses are mixed. The change can be seen as an adaptation output. In the context of the decline in party membership, Romanian parties had to make an important effort to preserve their high enrolment figures within a context where those members who made a marginal contribution to party finance (those contributing were in fact party leaders) continuously challenged the leadership status quo. The 2015-2016 changes can be seen as necessary adaptations to an increasingly tough 'political market' cluttered with new competitors from outside and increased tension from within. A complementary explanation points to a (slightly) different interpretation. The 2015-2016 reforms were based on an agreement between parliamentary parties in the form of an elite-based collusion endorsing a change that was fine-tuned to the new anticorruption drive. Parliamentary parties agreed to sacrifice their organisational impetus in exchange for a tacit agreement on downplaying the electoral competition (or at least the financial battles in organising the elections).

All in all, based on the evidence provided in this article, the 2015-2016 stateoriginated 'downgrading' of party members can be seen as first and foremost an attempt at self-preservation, ensuring the old parties retain their hegemonic position both with regard to the financial resources provided by the state and the number of new competitors. This observation is consistent with the cartel party thesis and the strategic attempts of parliamentary parties to limit political competition and ensure their own electoral success [Katz and Mair 2009]. Our analysis shows that party strategies for enrolment are more sensitive to political and financial benefits than to the costs of maintaining broad membership rolls (e.g. symbolic costs, patronage networks, etc.). Although the most recent reforms may have an influence on long-term party arrangements (such as a decline in en- 
rolment figures), in practice such provisions have constituted an opportunity for the mainstream parties to increase their incomes and reinforce the organisational status quo. Even if, in public, statements from parliamentary party leaders have often emphasised the financial 'waste' of the new party finance law, official party statements show record sums of money have been redirected towards the mainstream (parliamentary) parties.

AleXandRa IANCu is a senior lecturer in the Department of Political Science, University of Bucharest, teaching courses on comparative politics, European political parties, democratic transitions. Her recent publications include: La démocratie roumaine à ses débuts: Élitisme, apolitisme et informalité gouvernementale; Corruption politique en Europe (co-edited with Silvia Marton); and Party Members and Their Importance in Non-EU Countries. A Comparative Analysis (co-edited with Sorina Soare and Sergiu Ghergina).

SORINA SOARE is a lecturer at the University of Florence. Her research focuses on party politics, political participation, and Central and Eastern European politics. Her publications include Party Members and Their Importance in Non-EU Countries. A Comparative Analysis (co-edited with Alexandra Iancu and Sergiu Gherghina) and 'Deliberative Democracy and Political Parties: Functions and Consequences' in European Political Science (co-authored with Sergiu Gherghina, and Vincent Jacquet).

\section{References}

Achury, S., S. E. Scarrow, K. Kosiara-Pedersen and E. van Haute. 2018. 'The Consequences of Membership Incentives: Do Greater Political Benefits Attract Different Kinds of Members?' Party Politics. Online first, https://doi.org/10.1177/1354068818754603.

Casal Bértoa, F. and M. Spirova. 2013. 'Get a Subsidy or Perish! Public Funding and Party Survival in Eastern Europe. The Legal Regulation of Political Parties.' The Legal Regulation of Political Parties Working Paper 2013-029 Retrieved 4 June 2020 (http://www.partylaw.leidenuniv.nl/uploads/wp2913.pdf).

De Waele, J. M. and A. Ionașcu. 2008. 'La cohésion des cadres intermédiaires: un contrepoids aux divisions du parti? Le cas du Parti National Libéral Roumain.' Transitions 48 (1): 85-103.

Ganev, V. 2012. 'Post-accession Hooliganism: Democratic Governance in Bulgaria and Romania after 2007.' East European Politics and Societies 27 (1): 26-44, https:// doi.org/10.1177/0888325412465086.

Gauja, A. 2015. 'The Construction of Party Membership.' European Journal of Political Research 54 (2): 232-248, https://doi.org/10.1111/1475-6765.12078.

Gherghina, S. 2014. "'Shaping Parties" Legitimacy: Internal Regulations and Membership Organizations in Post-Communist Europe.' International Political Science Review 35 (3): 291-306, https://doi.org/10.1177/0192512113517125. 
Gherghina, S., A. Iancu and S. Soare. 2018. ‘Party Membership and Its Conceptualization in Democratizing European Countries: An Introduction.' Pp. 1-20 in Party Members and Their Importance in Non-EU Countries. A Comparative Analysis, edited by S. Gherghina, A. Iancu and S. Soare. London: Routledge, https://doi.org/10.4324/9781315201177-1.

Gîrlașiu, M. and S. Duță. 2017. 'Visul lui Dragnea: un milion de pesedişti până în 2018.' (Dragnea's dream: one million PSD members by 2018) Retrieved 15 June 2020 (https://jurnalul.antena3.ro/stiri/politica/visul-lui-dragnea-un-milion-de-pesedistipana-in-2018-755765.html).

Grzymała-Busse, A. M. 2002. Redeeming the Past: The Regeneration of Communist Parties in East Central Europe. Cambridge: Cambridge University Press.

Hazan, R. Y. and G. Rahat. 2010. Democracy within Parties: Candidate Selection Methods and their Political Consequences. Oxford: Oxford University Press, https://doi.org/10.1093/acprof:oso/9780199572540.001.0001.

Hotnews. 2015. 'Liviu Dragnea, ales presedinte PSD cu 96-97\% dintre voturile membrilor partidului.' (Liviu Dragnea, elected PSD president with $96-97 \%$ of the party members' votes) HotNews.ro, 12 October 2015. Retrieved 15 June 2020 (https://www.hotnews. ro/stiri-politic-20497863-liviu-dragnea-ales-presedinte-psd-96-97-dintre-voturilemembrilor-partidului-surse.htm).

Hotnews. 2018. 'Conducerea PNL a modificat procedura depunerii candidaturilor pentru alegerile europarlamentare.' HotNews.ro, 4 August 2018, https://www.hotnews.ro/stiri-esential-22603651-conducerea-pnl-modificatprocedura-depunerii-candidaturilor-pentru-alegerile-europarlamentare.htm.

Howard, M. 2003. The Weakness of Civil Society in Post-Communist Europe. Cambridge: Cambridge University Press, https://doi.org/10.1017/CBO9780511840012.

Iancu, A. 2017. 'Démocratisation et professionnalisation politique en Roumanie. Règles formelles et pratiques informelles de sélection gouvernementale.' Revue d'études comparatives Est-Ouest 48 (1-2): 297-328, https://doi.org/10.4074/S0338059917001103.

Ionaşcu, A. 2012. 'Lessons from a Divided Society: How to Deal with Party Factionalism.' Romanian Journal of Political Science 12 (1): 4-34.

Ionaşcu, A. and S. Soare. 2012. 'În căutarea unui Mecena. Mecanisme şi procese de finanțare ale partidelor politice în România postcomunistă.' (Looking for a Maecenas. The mechanisms and processes of party financing in post-communist Romania) Sfera Politicii 169: 56-64.

Katz, R. S. and M. Blyth. 2005. 'From Catch-All Politics to Cartelization: The Political Economy of the Cartel Party.' West European Politics 28 (1): 33-60, https://doi.org/10.1080/0140238042000297080.

Katz, R. S. and P. Mair. 2009. 'The Cartel Party Thesis: A Restatement'. Perspectives on Politics 7 (4): 753-766, https:/ / doi.org/10.1017/S1537592709991782.

Kölln, A-K. 2015. 'The Effects of Membership Decline on Party Organisations in Europe.' European Journal of Political Research 54 (4): 707-725, https://doi.org/10.1111/1475-6765.12110.

Kosiara-Pedersen, K., S. E. Scarrow and E. van Haute. 2017. 'Rules of Engagement? Party Membership Costs, New Forms of Party Affiliation, and Partisan Participation.' Pp. 234-259 in Organizing Political Parties Representation, Participation, and Power, edited by S. E. Scarrow, P. D. Webb and T. Poguntke. Oxford: Oxford University Press, https://doi.org/10.1093/oso/9780198758631.003.0010.

Mair, P. 2006. 'Ruling the Void? The Hollowing of Western Democracies.' New Left Review 42 (November-December): 25-51.

Mair, P. and I. van Biezen, . 2001. 'Party Membership in Twenty European Democracies: 1980-2000.' Party Politics 7 (1): 5-21, https://doi.org/10.1177/1354068801007001001. 
Mazzoleni, O. and G. Voerman. 2017. 'Memberless Parties. Beyond the Business-Firm Party Model?' Party Politics 23 (6) 783-792, https://doi.org/10.1177/1354068815627398.

Mungiu, A. 2018. 'Explaining Eastern Europe: Romania's Italian-Style Anticorruption Populism.' Journal of Democracy 29 (3): 104-116, https:// doi.org/10.1353/jod.2018.0048.

Pilet, J.-B. and W. Cross. (eds) 2014. The Selection of Political Party Leaders in Contemporary Parliamentary Democracies: A Comparative Study. London and New York: Routledge, https://doi.org/10.4324/9781315856025.

Poguntke, T., S. E. Scarrow, P. D. Webb, E. H. Allern, N. Aylott, I. van Biezen, E. Calossi, M. Costa Lobo, W. P. Cross, K. Deschouwer, Z. Enyedi, E. Fabre, D. M. Farrell, A. Gauja, E. Pizzimenti, P. Kopecký, R. Koole, W. C. Müller, K. Kosiara-Pedersen, G. Rahat, A. Szczerbiak, E. van Haute and T. Verge. 2016. ‘Party Rules, Party Resources and the Politics of Parliamentary Democracies: How Parties Organize in the 21st Century.' Party Politics 22 (6): 661-678, https://doi.org/10.1177/1354068816662493.

Pop-Elecheş, G. 2008. 'A Party for All Seasons: Electoral Adaptation of Romanian Communist Successor Parties.' Communist and Post-Communist Studies 41 (4): 465-479, https://doi.org/10.1016/j.postcomstud.2008.09.004.

Preda, C. and S. Soare. 2015. 'La Roumanie.' Pp. 395-411 in Les démocraties européennes. Institutions, élections et partis politiques, edited by N. Brack, J.-M. De Waele and J.-B. Pilet. Paris: Arman Colin.

Scarrow, S. 2015. Beyond Party Members: Changing Approaches to Partisan Mobilization. Oxford: Oxford University Press, https://doi.org/10.1093/acprof:oso/9780199661862.001.0001.

Scarrow, S. 2017. 'The Changing Nature of Political Party Membership.' Oxford Research Encyclopedia. Retrieved 15 July 2019 (https://oxfordre.com/politics/view/10.1093/ acrefore/9780190228637.001.0001/acrefore-9780190228637-e-226), https://doi.org/10.1093/acrefore/9780190228637.013.226.

Slăvoiu, V. 2018. 'Finanțarea partidelor politice în România: cine și de unde ia bani.' (Financing political parties in Romania: who pays and where the money comes from) România curată. Retrieved 15 June (http:/ / www.romaniacurata.ro/finantareapartidelor-politice-in-romania-cine-si-de-unde-ia-bani/).

Spirova, M. 2005. 'Political Parties in Bulgaria. Organisational Trends in Comparative Perspective.' Party Parties 11 (5): 601-622, https://doi.org/10.1177/1354068805054982.

Stan, L. 2010. 'Romania: In the Shadow of the Past.' Pp. 379-401 in Central and Southeast European Politics since 1989, edited by S. P. Ramet. Cambridge: Cambridge University Press, https://doi.org/10.1017/CBO9780511803185.021.

Tapalagă. D. 2018. 'Bugetul pentru finanțarea partidelor s-a dublat în 2018 față de anul trecut cu bani luați de la despăgubiri. De ce au nevoie partidele de mai multe fonduri de la buget.' (The budget for party financing doubled in 2018 with money taken from compensations. Why do parties need more funds from the national budget) G4Media, https://www.g4media.ro/bugetul-pentru-finantarea-partidelor-s-a-dublat-in-2018fata-de-anul-trecut-cu-bani-luati-de-la-despagubiri-de-ce-au-nevoie-partidele-de-maimulte-fonduri-de-la-buget.html.

van Biezen, I. 2003. Political Parties in New Democracies: Party Organization in Southern and East-Central Europe. London: Palgrave-Macmillan, https://doi.org/10.1057/9781403937858.

van Biezen, I., P. Mair and T. Poguntke. 2012. 'Going, Going, . . Gone? The Decline of Party Membership in Contemporary Europe.' European Journal of Political Research 51 (1): 24-56, https://doi.org/10.1111/j.1475-6765.2011.01995.x.

van Haute, E. and A. Gauja. (eds) 2015. Party Members and Activists. London: Routledge, https://doi.org/10.4324/9781315722214. 
Verba, S., N. H. Nie and J. Kim. 1978. Participation and Political Equality: A Seven-Nation Comparison. Cambridge: Cambridge University Press.

De Răzvan, F. 2016. 'De ce n-o să fiu niciodată destul de penibil ca să intru într-un partid politic din România.' Vice.com, 13 September 2016. Retrieved 15 June 2020 (https://www.vice.com/ro/article/vveygj/motive-sa-nu-intri-in-partidele-politicedin-romania). 


\section{Ranking objective and perceived inequality. A comparison of the Czech Republic in the European context}

\section{A comparison jirí Večerník a Martina Mysiková}

in the European context

In Czech public and professional discourse there is strong rhetoric about the rooted egalitarianism

Ranking objective and perceived inequality

A comparison of the Czech Republic in the European context

Jiří Večerník and Martina Mysíková

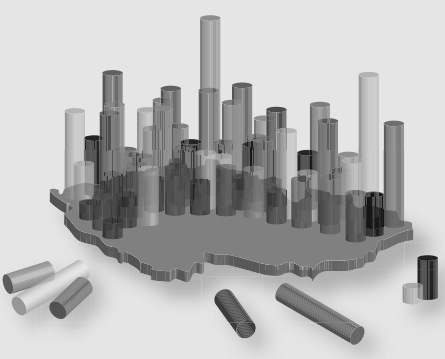

(1)

Institute of Sociology
Czech Academy of Sciences of Czech society and its extremely low socio-economic inequality. This study thus traces various objective and subjective dimensions of inequality in an attempt to examine the validity of this rhetoric. The study uses various sources of data on the levels and trends in earnings, household income, and living conditions in the Czech Republic and compares them to other European countries. It appears that although the country ranks among societies with a low level of social inequality, Czechs are not particularly 'exceptional' when it comes to objective economic equality, nor are they remarkably egalitarian in their attitudes.

Prague: Institute of Sociology of the Czech Academy of Sciences 125 pages

ISBN 978-80-7330-324-2

Available online: https://www.soc.cas.cz/en/publication/rankingobjective-and-perceived-inequality 